Abstracta Iranica Iranica

Revue bibliographique pour le domaine irano-aryen

Volume 29 | 2008

Comptes rendus des publications de 2006

\title{
Zabān-e hāl dar 'erfān va adabiyāt-e pārsī. Tehrān, Entešārāt-e Hermes, 1385/2006, 1142 p.
}

\section{Christine Van Ruymbeke}

\section{(2) OpenEdition}

1 Journals

\section{Édition électronique}

URL : http://journals.openedition.org/abstractairanica/31622

DOI : 10.4000/abstractairanica.31622

ISSN : 1961-960X

Éditeur :

CNRS (UMR 7528 Mondes iraniens et indiens), Éditions de l'IFRI

\section{Édition imprimée}

Date de publication : 15 mai 2008

ISSN : 0240-8910

\section{Référence électronique}

Christine Van Ruymbeke, "Zabān-e hạal dar 'erfān va adabiyāt-e pārsī. Tehrān, Entešārāt-e Hermes,

1385/2006, 1142 p. », Abstracta Iranica [En ligne], Volume 29 | 2008, document 337, mis en ligne le 15 septembre 2008, consulté le 26 septembre 2020. URL : http://journals.openedition.org/

abstractairanica/31622 ; DOI : https://doi.org/10.4000/abstractairanica.31622

Ce document a été généré automatiquement le 26 septembre 2020.

Tous droits réservés 


\title{
Zabān-e hāl dar 'erfān va adabiyāt-e pārsī. Tehrān, Entešārāt-e Hermes, 1385/2006, $1142 \mathrm{p}$.
}

\author{
Christine Van Ruymbeke
}

1 Cet important et savant ouvrage propose un aperçu de l'emploi et de la signification du « zabān-e hạāl » dans la littérature et la poésie mystique. Si le concept de cette « langue » employée pour traduire le dialogue intérieur, « la langue de l'état intérieur », est bien connu (p. 116 : la première apparition de l'expression « zabān-e hāal » se retrouvant dans des Quatrains de Hुayyām), nous n'en possédons pas de définition précise, peutêtre parce que le terme, qui se retrouve tout au long de l'histoire de la littérature persane, recouvre parfois des procédés différents suivant les auteurs. N. Pūrjavādī entend le concept de la manière la plus générale possible. Les animaux et les objets tout autant les hommes peuvent s'exprimer par le «zabān-e hāal » et ce n'est que dans la littérature contemporaine, chez certains auteurs, comme Forūg FarroHzzād, que Pūrjavādī reconnaît ne pas avoir trouvé trace du « zabān-e ḥāl ».

2 L'ouvrage propose une vaste recension de passages où se manifeste cette " voix intérieure », accompagnée d'explications (que l'on souhaiterait parfois plus détaillées, bien que ceci aurait été impossible dans un ouvrage de cette ampleur), qui non seulement contribuent à éclairer notre compréhension de ces passages littéraires, mais également mettent en lumière les différentes acceptions du concept chez les différents auteurs persans et dans les différents genres littéraires au cours des siècles. Le volume est divisé en trois parties. La première présente les principaux poètes ayant fait usage de ce langage particulier : ce vaste tour d'horizon débute par les traditions littéraires anciennes telles la littérature de Mésopotamie ou encore la littérature syriaque, pour ensuite se focaliser sur la littérature de l'Iran, d'abord pré-islamique, puis de l'époque classique et enfin, contemporaine. La deuxième partie est dédiée aux disputes littéraires (monāzere) employant ce procédé, que l'A. classifie selon les genres (par exemple les joutes entre le soleil et la lune, le glaive et le qalam, les saisons de l'année, la raison et l'amour...). Enfin, dans une troisième partie, le concept est examiné suivant 
les contextes littéraires dans lesquels il paraît (par exemple, les passages concernant la voix du Hātef invisible ou l'échelle de la connaissance, ceux mettant en scène la rose et le rossignol, ou encore le genre particulier des rowde et ta'ziye, les Jeux des Passions.)

3 N. Pūrjavādī nous propose ici le fruit d'une longue et minutieuse collecte - qu'il espère aussi exhaustive que possible - à travers la littérature persane classique. De nombreux textes inédits sont également examinés, ajoutant une valeur non négligeable à la présente étude. Le choix de l'A. de présenter un catalogue des occurrences du procédé est raisonné et soigneusement respecté (chaque citation est accompagnée de références renvoyant aux éditions ou aux manuscrits utilisés), les classifications différentes selon les parties de l'ouvrages permettent des rapprochements utiles à l'intérieur de l'œuvre individuelle de chaque poète étudié, mais aussi des rapprochements dans la manière dont certains genres sont traités aux cours de l'histoire de la littérature persane, ou dans un genre ou contexte littéraire donné. Une bibliographie et des indexes viennent compléter cet ouvrage indispensable pour l'étude poussée d'un phénomène littéraire de première importance en poésie persane.

INDEX

Thèmes : 11.1.1. Littérature persane classique

\section{AUTEURS}

CHRISTINE VAN RUYMBEKE

University of Cambridge 